\title{
Phantom tumour and heart failure
}

\author{
Rajeev Sandal, Aditya Jandial, Kundan Mishra, Pankaj Malhotra
}

Internal Medicine, Post Graduate Institute of Medical Education and Research, Chandigarh, India

\section{Correspondence to}

Dr Pankaj Malhotra,

hematpgi@gmail.com

Accepted 17 October 2018

\section{DESCRIPTION}

A 66-year-old man presented with progressive breathlessness for 1 week. Further history was consistent with orthopnoea and paroxysmal nocturnal dyspnoea. He was a known case of ischaemic heart disease, on medical management with poor compliance, for 5 years. On examination, blood pressure was $130 / 70 \mathrm{~mm} \mathrm{Hg}$, pulse rate 94 beats/min and respiratory rate 36 breaths/ min with $\mathrm{SpO}_{2} 92 \%$ at room air. $\mathrm{He}$ had raised jugular venous pressure (12 $\mathrm{cm}$ of water), bilateral pitting pedal oedema and bilateral basal crepitation on chest auscultation with gallop rhythm (LVS3). Echocardiography revealed systolic dysfunction with an ejection function of 30\%-35\%. His chest $\mathrm{X}$-ray (posteroanterior view) showed well-defined biconvex opacity on the right side of the lung (figure 1A), and lateral view showed well-defined lenticular opacities along the transverse and oblique fissure (figure 1B). He was diagnosed as congestive heart failure with phantom tumour. The patient was started on a diuretic (furosemide $20 \mathrm{mg}$ two times a day) along with supportive care. The patient improved gradually, and opacification disappeared after 5 days of diuretics. Hence, confirming the diagnosis of phantom tumour.

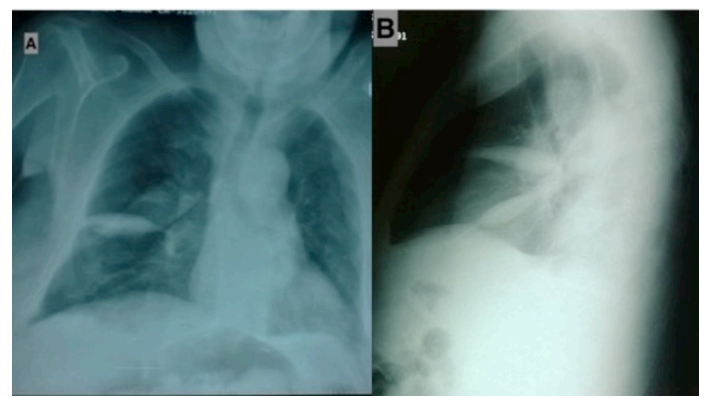

Figure 1 (A) Chest X-ray (posteroanterior view) showed well-defined biconvex opacity in right middle zone (phantom tumour). (B) Lateral view X-ray showed well-defined lenticular opacities along the transverse and oblique fissure (loculated pleural effusion).
Phantom tumour (or vanishing tumour) is a loculated transudative pleural effusion in the pulmonary fissure in the patient with volume overload, most commonly seen in congestive heart failure. ${ }^{1}$ Other conditions include renal failure, cirrhosis and hypoalbuminaemia. Chest X-ray shows well-defined lenticular opacity along the lung fissure, which is better localised on lateral view. ${ }^{2}$ Retraction force produced by the increased elastic recoil of the lung in the presence of underlying atelectatic lung is the proposed mechanism considered responsible. ${ }^{3}$ Pleuritis causing adhesions and obliteration in the pleural space also plays a key role in the pathogenesis. Treatment is diuretics along with treatment of the underlying aetiology.

\section{Learning points}

Phantom tumour also known as vanishing tumour is a loculated pleural effusion seen in conditions associated with fluid overload.

- It if fully reversible with diuretics and correction of the underlying disease.

- Knowledge of this entity may avoid unnecessary investigation and cost.

Contributors RS, AJ and KM wrote the manuscript. RS, AJ, KM and $P M$ were involved in patient management and collection of data. RS, AJ, KM and PM read the manuscript and vetted for the final manuscript.

Funding The authors have not declared a specific grant for this research from any funding agency in the public, commercial or not-for-profit sectors.

Competing interests None declared.

Patient consent Obtained.

Provenance and peer review Not commissioned; externally peer reviewed.

\section{REFERENCES}

1 Argan 0 , Ural D. Phantom tumor of the lung in heart failure patient. Turk J Emerg Med 2017:17:121-2.

2 Ye C, Wang J, Chai Y. Vanishing lung syndrome with air-fluid levels. Am J Med Sci 2016:352:e1.

3 Oliveira E, Manuel P, Alexandre J, et al. Phantom tumour of the lung. Lancet 2012;380:2028. 
Copyright 2018 BMJ Publishing Group. All rights reserved. For permission to reuse any of this content visit http://group.bmj.com/group/rights-licensing/permissions.

BMJ Case Report Fellows may re-use this article for personal use and teaching without any further permission.

Become a Fellow of BMJ Case Reports today and you can:

- Submit as many cases as you like

- Enjoy fast sympathetic peer review and rapid publication of accepted articles

Access all the published articles

- Re-use any of the published material for personal use and teaching without further permission

For information on Institutional Fellowships contact consortiasales@bmjgroup.com

Visit casereports.bmj.com for more articles like this and to become a Fellow 